\title{
PENINGKATAN LITERASI ANAK LKSA WIDHYA ASIH BADUNG MELALUI PELATIHAN READING DAN PUBLIC SPEAKING
}

\author{
Putu Chrisma Dewi', I Gusti Nyoman Putra Kamayana² \\ Fakultas Ekonomika dan Humaniora Universitas Dhyana Pura \\ ${ }^{1}$ chrismaindrawan@gmail com
}

\begin{abstract}
ABSTRAK
LKSA Widhya Asih Badung merupakan salah satu dari 6 cabang LKSA Widhya Asih yang tersebar di seluruh Bali. Masing-masing berlokasi di Badung, Melaya, Blimbingsari, Singaraja, Bangli, dan Amlapura Literasi bukan hanya sekadar kemampuan membaca dan menulis, tetapi kemampuan memanfaatkan teknologi, politik, berpikir kritis, dan peka terhadapi lingkungan sekitar. Literasi dapat juga diartikan sebagai kemampuan seseorang dalam menggunakan informasi untuk mengembangkan pengetahuan sehingga mendatangkan manfaat bagi masyarakat Untuk itu, anak-anak perlu diberikan pelatihan literasi, dalam bentuk kegiatan pelatihan membaca (mencari ide pokok bacaan), serta pelatihan public speaking, sehingga anak-anak bukan hanya bisa membaca, tetapi juga berbicara dengan baik. Sebanyak 4 (empat) kali pelatihan mencari ide pokok dan public speaking diberikan selama 1 (satu) bulan kepada 25 orang anak-anak LKSA. Untuk melihat keberhasilan dari pelatihan yang diberikan, sebelum kegiatan dimulai dilakukan pre-test, kemudian post-test dilakukan setelah kegiatan pelatihan. Setelah pelatihan, didapatkan hasil kemampuan anak-anak untuk menentukan ide pokok dalam sebuah bacaan meningkat dengan rata-rata 33,33\%, dan kemampuan public speaking anak meningkat hingga 11,11\%.
\end{abstract}

Kata kunci: literasi, membaca, ide pokok, berbicara

\section{PENDAHULUAN}

Di dalam Undang-Undang 1945 pasal 21 dijelaskan bahwa: "Panti asuhan adalah yayasan sosial badan hukum yang terdiri atas kekayaan yang dipisahkan dan diperuntukkan untuk mencapai tujuan tertentu di bidang sosial, keagamaan, dan kemanusiaan yang tidak mempunyai anggota. Yang didalammnya mengatur semua aktivitas dan pengolahan sarana penunjang kehidupan anak asuhnya." Depsos RI (2004:4) memaparkan bahwa: Panti sosial asuhan anak adalah suatu lembaga usaha kesejahteraan sosial pada anak terlantar dengan melaksanakan penyantunan dan pengentasan anak terlantar, memberikan pelayanan pengganti orang tua/wali anak dalam memenuhi kebutuhan fisik, mental dan sosial kepada anak asuh sehingga memperoleh kesempatan yang luas, tepat dan memadai bagi pengembangan kepribadiannya sesuai dengan yang diharapkan sebagai bagian dari generasi penerus cita-cita bangsa dan sebagai insan yang akan turut serta aktif dalam bidang pembangunan nasional.

LKSA Widhya Asih Badung merupakan salah satu dari 6 cabang LKSA Widhya Asih yang tersebar di seluruh Bali. Masing-masing berlokasi di Badung, Melaya, Blimbingsari, Singaraja, Bangli, dan Amlapura. Didampingi oleh 6 orang pendamping, LKSA Widhya Asih Badung membina 42 anak, yang terdiri dari 5 anak SD, 13 orang anak SMP, 24 orang anak SMA/K, dan 7 orang mahasiswa. Anak-anak yang telah menempuh pendidikan di perguruan tinggi tidak tinggal lagi di dalam LKSA, tetapi masih menjadi bagian dan tanggung jawab dari LKSA. Berlokasi di Jalan Raya Cica, Abianbase, LKSA 
ini memiliki bangunan baru yang sangat baik. Namun hal ini tidak serta merta membuat kehidupan di dalam panti tanpa masalah dan semua kebutuhan finansial terpenuhi dengan baik.

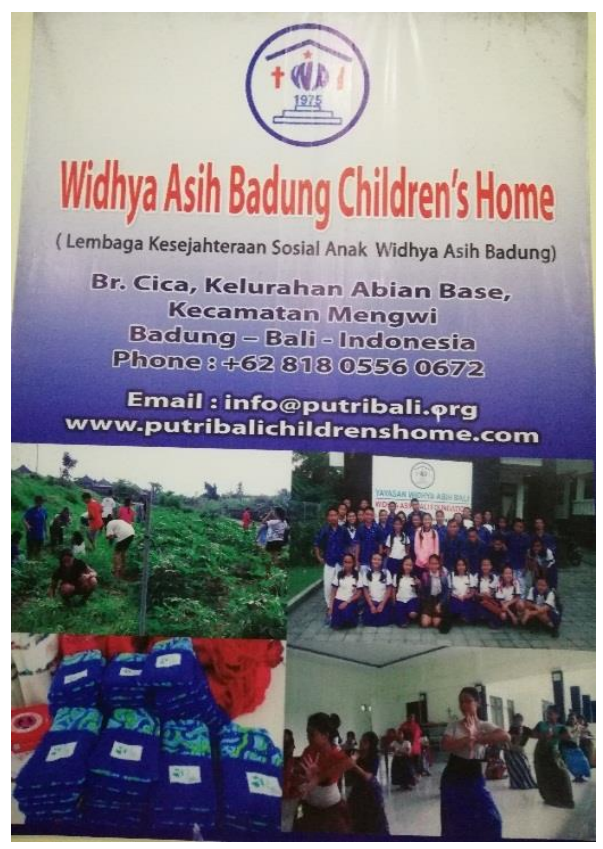

Banner LKSA Widhya Asih Badung

Secara periodik juga ada relawan (volunteer) yang datang antara lain membantu pengambangan Bahasa Inggris anak-anak LKSA. Namun di tahun 2018 dan 2019, tidak ada program untuk pelatihan Bahasa Inggris. Setidaknya ada 2 (dua) kali kunjungan dalam sebulannya. Saat ada kunjungan tamu dari luar negeri, beberapa anak sudah mulai dapat berkomunikasi dengan baik dan percaya diri dalam Bahasa Inggris dengan para tamu. Namun, kemampuan dan kepercayaan diri ini tidak secara merata dimiliki oleh anak-anak LKSA. Kepala LKSA memiliki kerinduan agar semua anak-anak LKSA dapat berkomunikasi dalam Bahasa Inggris dengan baik dan percaya diri. Ada 2 permasalahan yang akan dibahas dalam artikel ini:

1. Bagaimanakah peningkatan kemampuan anak-anak LKSA dalam mencari ide pokok suatu bacaan?

2. Bagaimanakah peningkatan kemampuan Bahasa Inggris anak-anak LKSA setelah mendapatkan pelatihan public speaking?

Untuk mengetahui peningkatan kemampuan anak-anak dalam mencari ide pokok menggunakan strategi SQ3R yang diadopsi oleh Burns d.k.k. 1996 (Khalik, 2008), yakni tahap membaca sekilas (survey), tahap menyusun pertanyaan (question), tahap membaca (reading), tahap menjawab pertanyaan (recite), dan tahap meninjau ulang (review). Sedangkan untuk mengetahui peningkatan kemampuan public speaking, anak-anak akan diberikan pelatihan pelafalan (pronunciation), tata bahasa (grammar), dan kosa kata (vocabulary).

\section{MATERI DATA DAN METODE}

Bahasa memegang peranan yang penting dalam kehidupan sehari-hari. Bahasa memberikan pengaruh yang besar dalam perkembangan anak. Dengan bahasa anak akan tumbuh dan berkembang menjadi manusia dewasa yang mampu bergaul di tengah-tengah 
masyarakat (Handayani, 2008). Bagi kebanyakan orang, berbicara di depan umum sangat menakutkan. Hal ini menggambarkan baik secara langsung maupun secara tidak langsung bahwa berbicara di depan umum merupakan kemampuan yang bila tidak dilatih maka akan menimbulkan gejala psikologis yang hebat pada seseorang yang belum terbiasa berbicara di depan umum. Selain permasalan berbicara, membaca juga memerlukan keahlian dan perlu dilatih secara khusus. Tarigan (1987:7) mendefinisikan membaca sebagai sebuah proses yang dilakukan dan digunakan oleh pembaca untuk memperoleh pesan yang hendak disampaikan oleh penulis melalui bahasa tulisan.

Penelitian dilaksanakan di LKSA Widhya Asih Badung, yang berlokasi di Jalan Raya Cica, Badung. Sebanyak 25 anak LKSA yang merupakan siswa SMP dan SMK ambil bagian dalam kegiatan pelatihan mencari ide pokok dan public speaking. Penelitian ini bersifat deskriptif-kuantitatif, dimana anak-anak diajak untuk melakukan pre-test sebelum diajarkan lalu diberikan pelatihan dalam mencari ide pokok dan melakukan public speaking. Setelah diberikan pelatihan, maka dilakukan post-test untuk mengukur peningkatan kemampuan. Pelatihan dilakukan sebanyak 4 kali sebelum post-test dilakukan.

\section{HASIL DAN PEMBAHASAN}

Sebanyak 25 anak berpartisipasi dalam kegiatan ini. Adapun kegiatan yang telah dilaksanakan, yaitu pelatihan reading (mencari ide pokok bacaan) dan pelatihan public speaking. Adapun rincian kegiatan yang dilaksanakan sebagai berikut:

1. Perkenalan dan pemaparan kegiatan

Pada sesi ini, tim berkunjung ke LKSA untuk melakukan perkenalan dan pemaparan kegiatan. Pada kegiatan ini dilakukan ice-breaking dan pengenalan kemampuan siswa melalui pre-test dan post-test tentang kempuan reading dan public speaking. Adapun kegiatan ini bertujuan untuk mengenali potensi anak dan menentukan apa yang menjadi kendala mereka dalam menghadapi reading dan public speaking.

2. Pelatihan membaca dan mencari ide pokok bacaan

Pelatihan dilakukan dengan memberikan bacaan dan soal singkat yang disesuaikan dengan tingkat pendidikan anak. Topiknya tentang planet and solar system dan major art movement in the history. Anak diminta untuk membaca teks, mencari kata-kata sulit, memahami maksud dari bacaan, lalu menetukan main idea dan supporting details dari bacaan tersebut.

3. Pelatihan public speaking

Pelatihan public speaking dilakukan dengan mengajak anak untuk memperkenalkan diri dan menceritakan tentang kegiatan mereka sehari-hari. Kegiatan fokus pada pelafalan, ketepatan gramatikal, dan meningkatkan kepercayaan diri anak dalam berbicara. Pada saat pre-test anak-anak diminta untuk mengungkapkan apa yang menjadi kendala mereka ketika belajar Bahasa Inggris, khususnya untuk membaca dan berbicara. Dari 25 anak, sebanyak 20 anak menjawab permasalahan ketika membaca adalah kosakata yang sulit dipahami dan 21 anak menjawab kesulitan mencari ide pokok. Sedangkan permasalahan ketika berbicara adalah 25 anak menjawab tidak percaya diri, 22 anak menjawab karena kurangnya kosakata, dan 23 anak menjawab takut salah (kesalahan grammatical).

Setelah melakukan pre-test untuk mengetahui apa yang menjadi kendala yang dihadapi oleh mitra, maka tim PKM memberikan pelatihan:

1. Pelatihan membaca (mencari ide pokok)

Saat pelatihan membaca, khususnya mencari ide pokok dari suatu bacaan. Anak-anak diberikan 1 (satu) teks narasi pendek dengan 3 (tiga) soal yang harus dijawab 
berdasarkan bacaan. Hasil pre-test menunjukkan dari 25 orang, 18 orang benar menjawab soal nomor 1, 13 orang benar menjawab soal nomor 2 , dan 10 orang benar menjawab soal nomor 3 .

Setelah melakukan pre-test, dan mendapatkan hasil jawaban dari anak-anak, tim lalu melakukan pelatihan dengan membahas teknik-teknik yang harus dilakukan ketika anak-anak harus mencari ide pokok suatu bacaan. Pada saat latihan, anak-anak juga diberikan soal model serupa dengan pre-test untuk berlatih mencari ide pokok dari suatu bacaan. Soal latihan sebanyak 2 buah. Setelah selesai membahas soal latihan, lalu dilanjutkan dengan memberikan post-test dengan soal yang sama seperti pre-test. Berikut adalah tabel perbandingan hasil Pre-Test dan Post-Test setelah anak-anak LKSA diberikan pelatihan pencarian ide pokok sebanyak 4 (empat) kali.

Tabel Perbandingan Hasil Pre-Test dan Post-Test Pencarian Ide Pokok Bacaan

\begin{tabular}{|c|c|c|}
\hline SOAL NOMOR & $\begin{array}{c}\text { PRE-TEST } \\
\text { (Jumlah benar) }\end{array}$ & $\begin{array}{c}\text { POST-TEST } \\
\text { (Jumlah benar) }\end{array}$ \\
\hline 1 & 18 orang & 25 orang \\
\hline $2 . \mathrm{a}$ & 13 orang & 21 orang \\
\hline $2 . \mathrm{b}$ & 10 orang & 20 orang \\
\hline
\end{tabular}

Hasil post-test menunjukkan, dari 25 anak semua anak berhasil menjawab soal nomor 1 dengan benar, 21 anak menjawab soal nomor 2 dengan benar, dan 20 anak menjawab soal nomor 3 dengan benar. Adapun peningkatannya kemampuannya sekitar 33,33\%.

\section{Pelatihan public speaking}

Pelatihan public speaking yang dilakukan berbentuk cara perkenalan diri dan kemampuan menceritakan aktivitas sehari-hari. Sebelumnya dilakukan pre-test terhadap perwakilan masing-masing group (dibagi menjadi 4 group). Perwakilan group melakukan perkenalan diri kemudian menceritakan apa saja yang menjadi aktivitas mereka. Ketika mereka berbicara ada 4 (empat) komponen yang dinilai yakni pronunciation, grammar, vocabulary, dan fluency. setelah dilakukan pre-test dan mengetahui apa saja yang menjadi kendala anak, maka diberikan pelatihan singkat seperti:

1. Salam

2. Pengenalan tentang simple present tense

3. Membuat daftar kata kerja terkait topik (memperkenalkan diri)

4. Melatih kepercayaan diri

Berikut adalah tabel hasil perbandingan hasil Pre-Test dan Post-Test setelah anakanak diberikan pelatihan public speaking sebanyak 4 (empat) kali.

Tabel Perbandingan Hasil Pre-Test dan Post-Test Public Speaking

\begin{tabular}{|c|c|c|c|c|c|c|c|c|}
\hline \multirow{3}{*}{ SISWA } & PRONUNCIATION & \multicolumn{2}{|c|}{ GRAMMAR } & \multicolumn{2}{|c|}{ VOCABULARY } & \multicolumn{2}{|c|}{ FLUENCY } \\
\cline { 2 - 9 } & $\begin{array}{c}\text { Pre- } \\
\text { Test }\end{array}$ & $\begin{array}{c}\text { Post- } \\
\text { Test }\end{array}$ & $\begin{array}{c}\text { Pre- } \\
\text { Test }\end{array}$ & $\begin{array}{c}\text { Post- } \\
\text { Test }\end{array}$ & $\begin{array}{c}\text { Pre- } \\
\text { Test }\end{array}$ & $\begin{array}{c}\text { Post- } \\
\text { Test }\end{array}$ & $\begin{array}{c}\text { Pre- } \\
\text { Test }\end{array}$ & $\begin{array}{c}\text { Post- } \\
\text { Test }\end{array}$ \\
\hline A & 65 & 70 & 70 & 75 & 70 & 75 & 60 & 70 \\
\hline B & 70 & 75 & 75 & 80 & 75 & 80 & 70 & 75 \\
\hline C & 70 & 75 & 70 & 75 & 70 & 75 & 70 & 75 \\
\hline D & 70 & 80 & 75 & 80 & 70 & 75 & 70 & 80 \\
\hline
\end{tabular}

Hasil post-test menunjukkan terjadi peningkatan sebesar 9,09\% untuk pronunciation, $6,80 \%$ untuk grammar, $5,10 \%$ untuk vocabulary, dan $11,11 \%$ untuk fluency. Tentunya 
hasil dapat meningkat lebih lagi jika anak tetap konsisten dalam berlatih dan menjaga kepercayaan diri mereka.

\section{SIMPULAN}

Membaca dan berbicara merupakan 2 (dua) skill yang wajib dikuasai oleh setiap orang. Untuk memahami bacaan dan mampu berbicara dalam Bahasa Inggris, diperlukan pelatihan khusus untuk meningkatkan kemampuan tersebut. Telah dilakukan penelitian tentang peningkatan kemampuan anak LKSA Widhya Asih dengan memberikan pelatihan mencari ide pokok suatu bacaan dan pelatihan public speaking. Setelah dilakukan pelatihan membaca, kemampuan anak-anak untuk menentukan ide pokok dalam sebuah bacaan meningkat dengan rata-rata $33,33 \%$, dan kemampuan public speaking anak meningkat hingga $11,11 \%$.

\section{DAFTAR PUSTAKA}

Ardiana. (1990). Penelitian Tindakan Kelas (PTK). Jakarta: Depdiknas.

Handayani, Putri Ayu. 2008. Pentingnya Peningkatan Keterampilan Berbicara pada Anak Usia Dini Melalui Metode Bercakap-Cakap. Bandung: Sekolah Sekolah Tinggi Keguruan Dan Ilmu Pendidikan.

Khalik. 2000. Pengajaran Bahasa Indoensia 1. Jakarta. Depdikbud.

Kompas. Rabu, 1 Juni 2016. "Budayakan Literasi". Pendidikan dan Kebudayaaan. Hlm. 12.

Kharizmi, M. (2015). Kesulitan Siswa Sekolah Dasar dalam Meningkatkan Kemampuan Literasi. JUPENDAS, ISSN 2355-3650, Vol. 2, No. 2, September 2015.

Metsi Adalla, Sahrudin Barasandji, dan Pratama Bayu Santosa. Meningkatkan Kemampuan Menentukan Ide Pokok Paragraf Siswa IV SDN Boloak Melalui Metode Tutor Sebaya Jurnal Kreatif Tadulako Online Vol. 5 No. 1 ISSN 2354-614X.

Musthafa, B. (2014). Literasi Dini dan Literasi Remaja: Teori, Konsep, dan Praktik. Bandung: CREST.

Tarigan, H.G. (1987). Membaca sebagai Suatu Keterampilan Berbahasa. Bandung: Angkasa.

Yuliati, Nova. Roxhim, Muhammad. Lilis, Dede. 2014. Pelatihan Keteramipan Dasar Public Speaking bagi Siswa SMA di Kota Bandung. Dapat diakses dari: http://prosiding.lppm.unisba.ac.id/index.php/sosial/article/viewFile/158/96. 